\title{
Assessment of quality benchmarks in adenoma detection in Mexico
}

\section{다 (ㄱ) $\odot$}

\section{Authors}

Nancy E. Aguilar-Olivos' ${ }^{1}$, Ricardo Balanzá1, Fernando Rojas-Mendoza', Rodrigo Soto-Solis², Mario A. BallesterosAmozurrutia² $^{2}$ Norma González-Uribe², Justo A. Fernández-Rivero' ${ }^{1}$

Institutions

1 Medica Sur Hospital, Gastroenterology and Endoscopy Unit, Mexico City, Mexico

2 Angeles Pedregral Hospital, Gastroenterology and Endoscopy Unit, Mexico City, Mexico

submitted 27.8.2020

accepted after revision 22.1.2021

\section{Bibliography}

Endosc Int Open 2021; 09: E796-E801

DOI 10.1055/a-1396-3718

ISSN 2364-3722

(c) 2021. The Author(s).

This is an open access article published by Thieme under the terms of the Creative Commons Attribution-NonDerivative-NonCommercial License, permitting copying and reproduction so long as the original work is given appropriate credit. Contents may not be used for commercial purposes, or adapted, remixed, transformed or built upon. (https://creativecommons.org/licenses/by-nc-nd/4.0/)

Georg Thieme Verlag KG, Rüdigerstraße 14,

70469 Stuttgart, Germany

\section{Corresponding author}

Nancy E. Aguilar-Olivos, MD, MSc, Gastroenterology and Endoscopy Unit, Médica Sur Hospital, Puente de Piedra 150, Col. Toriello Guerra, ZP. 14050, Mexico City, Mexico Fax: +525554247200

dra.nancy.aguilar@gmail.com

\section{ABSTRACT}

Background and study aims Several Latin American countries, including Mexico, have reported an increase in colorectal cancer (CRC) mortality. The effectiveness of a colonoscopy in preventing CRC depends on the quality of the procedure, for which the adenoma detection rate (ADR) is one of the most trusted indicators. Awareness of ADR can improve the quality of colonoscopies through proper feedback and training of the specialists. The goal of this study was to estimate the ADR among Mexican endoscopists with experience in CRC screening and to compare it with previously reported data from this country.

Methods We carried out a retrospective study to analyze ADR data in Mexico. The information was obtained from a group of certified endoscopists and compared with the former published data from Mexico.

Results We found a current ADR of $24.6 \%$ ( $95 \% \mathrm{Cl}, 22.4 \%$ $26.8 \%$ ) from 1,478 colonoscopies performed by eight endoscopists in two third-level private hospitals. The average ADR reported in previous publications was 15.2\% (95\% $\mathrm{Cl}, 13.3 \%-17.1 \%)$. Statistical analysis showed differences between our results and those from previous studies ( $24.6 \%$ vs. $15.2 \%, P<0.001)$.

Conclusions The actual ADR in Mexico is higher than previously reported. Previous low ADR values could be explained by poorly performed colonoscopies rather than by low adenoma and CRC incidence in our country.

\section{Introduction}

Worldwide, colorectal cancer (CRC) is the third most common cancer within the category of newly diagnosed types of cancer and the second leading cause of death related to cancer. In Mexico, CRC is the fourth most commonly diagnosed type of cancer and the sixth cause of death related to cancer. In 2018, there were 1,849,518 new cases of CRC in the world and 880,792 deaths; in Mexico, there were a total of 10,457 newly diagnosed CRC cases and roughly 5,700 deaths [1].

CRC incidence and mortality rates have stabilized or even declined in a number of high human development index countries such as the United States, Australia, New Zealand, and sev- eral Western European countries. One of the reasons is the increased early detection and prevention through diagnostic screening procedures such as colonoscopy with polypectomy. On the other hand, several countries in Latin America, the Caribbean, and Asia, with limited health infrastructure and poorer access to early detection and treatment have reported increasing CRC mortality [2].

There are two main types of precancerous lesions in the coIon, namely conventional adenomas and serrated lesions. Adenomas are the precursors of $70 \%$ of all CRC cases and are generated in the adenoma-carcinoma sequence, which is believed to take more than 10 years in completing its growth in sporadic cancers [3]. The U.S.Multi-Society Task Force on Colorectal 
Cancer recommends offering CRC screening to average-risk individuals and those without a high-risk family history of colorectal neoplasia, beginning at the age of 50 years; a colonoscopy every 10 years, annual fecal immunochemical testing (FIT), CT colonography every 5 years, FIT-fecal DNA every 3 years, flexible sigmoidoscopy every 5 to 10 years, and capsule colonoscopy every 5 years, all of which are considered appropriate screening tests for the detection of early CRC or precancerous lesions [3].

The optimal effectiveness of colonoscopy in preventing CRC depends on the quality of the procedure. This quality can be measured by comparing the performance of an endoscopist with a standard reference or benchmark [4]. The specific parameter used for comparisons is called a "quality indicator." The quality indicators for colonoscopy that have been found to decrease CRC incidence and mortality rates are: 1 . frequency of adequate bowel preparation; 2 . use of recommended surveillance intervals; 3 . cecal intubation rate; 4 . withdrawal time; and 5. adenoma detection rate (ADR) [4].

The American Society for Gastrointestinal Endoscopy (ASGE) and the European Society of Gastrointestinal Endoscopy (ESGE) recommend a minimum target for overall ADR of at least $25 \%$, with specific rates of $30 \%$ for men and $20 \%$ for women $[4,5]$. These recommendations aim to improve ADR results, as it has been shown that for each $1 \%$ increase in ADR there is a $3 \%$ reduction in CRC incidence and a $5 \%$ reduction in cancer mortality $[6,7]$. Knowledge of the ADR allows improving the quality of colonoscopies through proper feedback and training of the endoscopists [8].

The increase in CRC incidence and mortality over the past 10 years in Latin American countries, including Mexico, may be explained by delays in diagnosis, referral, and treatment, as well as financial constraints [2]. Also, countries with low ADR perform poorly in the identification of patients with precancerous lesions and increased CRC risk due to failure to clear the colon. Hence, the objective of this study was to evaluate the current ADR among Mexican endoscopists with experience in CRC screening and to compare their results with those shown in published reports from this country.

\section{Patients and methods}

\section{Study design and patients}

We carried out a retrospective study to analyze the performance of experienced endoscopists at two endoscopy units from tertiary care private hospitals in Mexico City. The study protocol was reviewed and approved by the Institutional Review Boards of both centers.

The research included individuals older than 50 years who underwent screening or diagnostic colonoscopy from July 2012 to June 2014 in center number 1 and from January 2015 to December 2016 in center number 2. We were not able to include data from 2017 onward because some of the endoscopists that participated in this study also participated in other protocols. Patients were excluded if they had previously been diagnosed with CRC, had suffered any surgical resection of the colon, had history of any polyp syndrome, Lynch syndrome or inflammatory bowel disease, had indication of a therapeutic procedure, incomplete colonoscopy, or an inadequate bowel preparation. The latter was defined as a score of 5 or less in total or 1 or less in any of the segments in accordance with the Boston Bowel Preparation Scale (BBPS). Patients were also excluded if there was no available pathology report or the colonoscopy was device-assisted.

\section{Endoscopic procedures}

Each physician had performed a minimum of 400 colonoscopies, with an average of more than 200 general colonoscopies per year, and aside from having received fellowship training, they were certified by the Mexican Gastroenterology Board. All the procedures were performed using the EVIS EXERA II CV-180 video processor (Olympus, Tokyo, Japan) and CF-H180AL model colonoscopes (Olympus, Tokyo, Japan). The procedures were done under intravenous sedation supervised by an anesthesiologist with Board certification. No fellows in gastroenterology or gastrointestinal endoscopy participated in the colonoscopies.

\section{Data collection and study outcome}

Patient information including socio-demographics, procedure results, and pathology reports were accessed for this study after careful review of the electronic medical records. The primary outcome was the ADR analysis in order to compare it with reported data from Mexico. Secondary outcomes included the polyp detection rate (PDR), the mean number of adenomas per colonoscopy (APC) and, the advanced adenoma detection rate (AADR). ADR, PDR and AADR are defined by the proportion of patients aged 50 years or older undergoing screening or diagnostic colonoscopy with at least one histologically proven adenoma, polyp, or advanced adenoma, respectively $[5,9,10]$. Advanced adenoma was defined as a lesion with villous features, high-grade dysplasia, or size greater than $10 \mathrm{~mm}$. The APC was defined as the total number of adenomas divided by the total number of colonoscopies performed [10]. These secondary targets were investigated only in center number 2 .

\section{Literature overview}

We performed an electronic search in Medline and Google Scholar databases to identify all the articles that reported ADR in Mexico. We also conducted a manual search looking for additional relevant articles. Our research went as far as April 30, 2020; articles in English and Spanish were both included at this stage. All groups of patients and interventions were analyzed to obtain the individual data needed to calculate a pooled ADR.

\section{Statistical analysis}

Descriptive statistics with frequency and percentages were used to determine socio-demographic characteristics. ADR, PDR, and AADR were presented as percentages with $95 \%$ confidence intervals, while APC was described by average estimates. ADR groups comparisons were made using a chi-square test. $P$ $<0.05$ was considered statistically significant. All statistical analyses were performed using a standard software package (Stata, version. 14.1; StataCorp). 


\section{Results}

\section{Baseline characteristics}

From July 2012 to June 2014, a total of 1,344 colonoscopies were performed at center number 1 by four practicing endoscopists and from January 2015 to December 2016, a total of 1,218 colonoscopies were performed at center number 2 by another four practicing endoscopists. After application of inclusion and exclusion criteria, 879 screening colonoscopies from center number 1 and 599 screening colonoscopies from center number 2 were included in our study, with a total of 1,478 endoscopic procedures performed by 8 endoscopists. The median age of the population sample was 64 years and $47 \%$ of subjects were male. No significant differences were found between the two centers.

\section{Primary outcome}

The global ADR of the 1,478 colonoscopies included in the study was $24.6 \%$ ( $95 \% \mathrm{Cl}, 22.4 \%-26.8 \%)$. For center number 1 , the mean ADR was $24.0 \%(95 \% \mathrm{Cl}, 21.2 \%-26.8 \%)$, and for center number 2 , the mean ADR was $25.5 \%(95 \% \mathrm{Cl}, 22.1 \%-$ $29.0 \%$ ). Individually, ADRs ranged between $19.2 \%$ and $30 \%$ ( $\downarrow$ Table 1). The percentage of adenomas measuring $>10 \mathrm{~mm}$ was $4.3 \%(95 \% \mathrm{Cl}, 2.9 \%-6.3 \%)$ and CRC was diagnosed in $1.3 \%$ $(95 \% \mathrm{Cl}, 0.7 \%-2.7 \%)$ of the colonoscopies performed in center number 2 . There is no data regarding polyp size nor CRC prevalence from center number 1.

As for relevant literature, we found seven articles that reported 11 ADR values ( $>$ Table 2 ). The ADR presented a wide range of values, varying from $5.8 \%$ to $30.7 \%$ [11-17]. Four of these papers were comparative studies, 3 of them compared conventional versus endocuff-assisted colonoscopies [12-14]; in the fourth one, a tandem design was employed, comparing the index and second colonoscopies after improvement of colon cleansing according to the BBPS [15]. ADR values from endocuff-assisted colonoscopies were excluded. The average ADR was $15.2 \%(95 \% \mathrm{Cl}, 13.3 \%-17.1 \%)$, while the ADR obtained from colonoscopies in our study was $24.6 \%(216 / 1,422$ [15.2\%] vs. 364/1,478 [24.6\%]; $P<0.001)$ ( Fig.1).

\section{Secondary outcomes}

The PDR, AADR, and APC were all analyzed by the 4 endoscopists from center number 2 (> Fig.2). The PDR was $39.1 \%$ (95\%Cl, 35.1\%-43.1\%); advanced adenomas were detected in 31 out of 599 colonoscopies, with an AADR of $5.2 \%(95 \% \mathrm{Cl}$, $3.5 \%-7.3 \%$ ); lastly, a total of 247 adenomas were detected in 599 colonoscopies by the 4 endoscopists from center number 2, with an APC mean of 0.41 (range 0.33 to 0.53 ).

\section{Discussion}

The average ADR in our study was $24.6 \%$, which almost meets the criteria set in the latest ESGE and ASGE guidelines [4, 5]. The ADR from center number 1 was $24.0 \%$, whereas the ADR from center number 2 was $25.5 \%$. Center number 2 did fulfill the benchmark for ADR as a quality indicator. These percentages are derived from the ESGE and ASGE guidelines, both based
- Table 1 Adenoma detection rate per endoscopist.

\begin{tabular}{|l|l|l|l|}
\hline $\begin{array}{l}\text { Endoscopy } \\
\text { unit }\end{array}$ & $\begin{array}{l}\text { Endos- } \\
\text { copist }\end{array}$ & $\begin{array}{l}\text { Colonos- } \\
\text { copies (n) }\end{array}$ & $\begin{array}{l}\text { Adenoma Detec- } \\
\text { tion Rate (\%) }\end{array}$ \\
\hline Center 1 & 1 & 300 & 22.6 \\
\hline & 2 & 204 & 30.4 \\
\hline & 3 & 125 & 19.2 \\
\hline & 4 & 250 & 22.8 \\
\hline & 5 & 165 & 24.8 \\
\hline & 6 & 144 & 29.2 \\
\hline & 7 & 185 & 22.2 \\
\hline & 8 & 105 & 27.6 \\
\hline
\end{tabular}

on data from western countries. CRC incidence can vary widely between countries, the age-standardized incidence rate per 100,000 persons according to data derived from the GLOBOCAN 2018 is 11.2 for Mexico, 32.1 for the United Kingdom, 25.6 for the United States, and 4.4 for India [1]. The ADR may be affected by the mentioned CRC incidences. Endoscopists in the United States of America have reported ADRs as high as $70 \%$ in Endocuff-assisted colonoscopies, while Indian literature shows an ADR of $6.7 \%$ [18, 19]. In Mexico Endocuff-assisted colonoscopy has provided an ADR of $44 \%$ [12]. ADR benchmarks need to be defined by country, however information to make this possible is still missing. We believe that the current ADR benchmark could be different among countries according CCR incidence; but the information to support this statement is unavailable. Published studies from Mexico reported an ADR ranging from $5.8 \%$ to $30.7 \%$ ( $\triangleright$ Table 2 ) [11-17]. The pooled ADR from colonoscopies in these publications was $15.2 \%$. These data would seem indicate that the Mexican population has a low prevalence of adenomas and CRC. Nevertheless, the ADR in our study was $24.6 \%$, showing a statistically significant difference when compared with reported ADRs (> Fig.1). It is important to highlight that the studies included in $>$ Table 2 show a significant heterogeneity in terms of the methodological design, characteristics of the centers, operators and inclusion criteria. This can cause different ADR results and limit the comparison; however, this information shows us the data from our country, as a region with low ADRs and, calls for awareness about the urgency of achieving the goals of CCR screening. CRC is the fourth most commonly diagnosed type of cancer in Mexico, which makes us believe that the true adenoma prevalence in Mexico is much higher than reported. The ADR value of $15.2 \%$ found in Mexican studies may reflect the performance of low-quality colonoscopies carried out in many Mexican centers and calls for quality improvement actions that could in turn improve the ADR. Further, competency in colonoscopy is achieved after 400 procedures during a Gastrointestinal Endoscopy fellowship and by maintaining a colonoscopy volume of over 200 procedures per year [20,21].

In Germany for example, increased awareness of quality control through the German Screening Colonoscopy Program re- 
- Table 2 ADR reported in previously published studies in Mexico.

\begin{tabular}{|c|c|c|c|c|c|c|c|c|c|}
\hline Authors & $\begin{array}{l}\text { Publish- } \\
\text { ing year }\end{array}$ & $\begin{array}{l}\text { Study } \\
\text { design }\end{array}$ & Location & $\begin{array}{l}\text { Fellow } \\
\text { partici- } \\
\text { pation }\end{array}$ & Inclusion criteria & $\begin{array}{l}\text { Colo- } \\
\text { nosco- } \\
\text { pies (n) }\end{array}$ & $\begin{array}{l}\text { Mean } \\
\text { BBPS }\end{array}$ & $\begin{array}{l}\text { Mean age } \\
\text { (years) }\end{array}$ & ADR (\%) \\
\hline $\begin{array}{l}\text { Gutiérrez- } \\
\text { Serrano RI, } \\
\text { et al. [11]. }\end{array}$ & 2019 & $\begin{array}{l}\text { Retrospec- } \\
\text { tive }\end{array}$ & $\begin{array}{l}\text { Second- } \\
\text { level pub- } \\
\text { lic hospital }\end{array}$ & NA & $\begin{array}{l}15 \text { to } 85 \text { years old } \\
\text { First colonoscopy } \\
\text { IBS }\end{array}$ & CC 233 & NA & $71 \%>50$ & CC 13.3 \\
\hline $\begin{array}{l}\text { Andujar- } \\
\text { Amor MA, } \\
\text { et al. [12] }\end{array}$ & 2018 & $\begin{array}{l}\text { Prospec- } \\
\text { tive } \\
\text { Compara- } \\
\text { tive }\end{array}$ & $\begin{array}{l}\text { Third-level } \\
\text { public } \\
\text { hospital }\end{array}$ & Yes & $\begin{array}{l}>18 \text { years old } \\
\text { Screening and sur- } \\
\text { veillance colonos- } \\
\text { copies }\end{array}$ & $\begin{array}{l}\text { CC } 50 \\
\text { EAC } 50\end{array}$ & NA & $\begin{array}{l}\text { CC } 46 \\
\text { EAC } 44\end{array}$ & $\begin{array}{l}\text { CC } 28 \\
\text { EAC } 44\end{array}$ \\
\hline $\begin{array}{l}\text { González- } \\
\text { Fernandez } \\
\text { C, et al. [13] }\end{array}$ & 2017 & $\begin{array}{l}\text { Prospec- } \\
\text { tive } \\
\text { Compara- } \\
\text { tive }\end{array}$ & $\begin{array}{l}\text { Third-level } \\
\text { public } \\
\text { hospital }\end{array}$ & Yes & $\begin{array}{l}>50 \text { years old } \\
\text { Screening colo- } \\
\text { noscopy }\end{array}$ & $\begin{array}{l}\text { CC } 163 \\
\text { EAC } 174\end{array}$ & $\begin{array}{l}\text { CC } 7 \\
\text { EAC } 7\end{array}$ & $\begin{array}{l}\text { CC } 62 \\
\text { EAC } 60\end{array}$ & $\begin{array}{l}\text { CC } 13.5 \\
\text { EAC } 22.4\end{array}$ \\
\hline $\begin{array}{l}\text { Peniche- } \\
\text { Moguel PA } \\
\text { et al. [14] }\end{array}$ & 2016 & $\begin{array}{l}\text { Prospec- } \\
\text { tive } \\
\text { Compara- } \\
\text { tive }\end{array}$ & $\begin{array}{l}\text { Third-level } \\
\text { public } \\
\text { hospital }\end{array}$ & NA & $>18$ years-old & $\begin{array}{l}\text { CC } 72 \\
\text { EAC } 73\end{array}$ & $\begin{array}{l}\text { CC } 7.04 \\
\text { EAC } 7.11\end{array}$ & Total 53 & $\begin{array}{l}\text { CC } 13.7 \\
\text { EAC } 31.9\end{array}$ \\
\hline $\begin{array}{l}\text { Zamora- } \\
\text { Morales M, } \\
\text { et al. [15] }\end{array}$ & 2016 & $\begin{array}{l}\text { Prospec- } \\
\text { tive } \\
\text { Compara- } \\
\text { tive }\end{array}$ & $\begin{array}{l}\text { Third-level } \\
\text { public } \\
\text { hospital }\end{array}$ & NA & $\begin{array}{l}>50 \text { years-old } \\
\text { FC: BBPS } \leq 5\end{array}$ & $\begin{array}{l}\text { FC } 52 \\
\text { SC } 52\end{array}$ & $\begin{array}{l}\text { FC } 4.37 \\
\text { SC } 7.38\end{array}$ & Total 56 & $\begin{array}{l}\text { FC } 5.8 \\
\text { SC } 30.7\end{array}$ \\
\hline $\begin{array}{l}\text { García-Oso- } \\
\text { gobio S, et } \\
\text { al. [16] }\end{array}$ & 2015 & $\begin{array}{l}\text { Prospec- } \\
\text { tive }\end{array}$ & $\begin{array}{l}\text { Third-level } \\
\text { private } \\
\text { hospital }\end{array}$ & No & $\begin{array}{l}40 \text { to } 79 \text { years old } \\
\text { First colonoscopy }\end{array}$ & CC 99 & CC 7.91 & CC 50 & 17 \\
\hline $\begin{array}{l}\text { Lascurain- } \\
\text { Morhan E, } \\
\text { et al. [17] }\end{array}$ & 2001 & $\begin{array}{l}\text { Retrospec- } \\
\text { tive }\end{array}$ & $\begin{array}{l}\text { Third-level } \\
\text { private } \\
\text { hospital }\end{array}$ & No & $\begin{array}{l}\text { Rectosigmoido- } \\
\text { scopy }\end{array}$ & CC 701 & CCNA & CC 55 & 14.7 \\
\hline
\end{tabular}

ADR, adenoma detection rate; BBPS, Boston Bowel Preparation Scale; CC, conventional colonoscopy; EAC, Endocuff-assisted colonoscopy; FC, first colonoscopy with fair-poor BBPS; SC, second colonoscopy with improved BBPS; IBS, irritable bowel syndrome; NA, data not available.

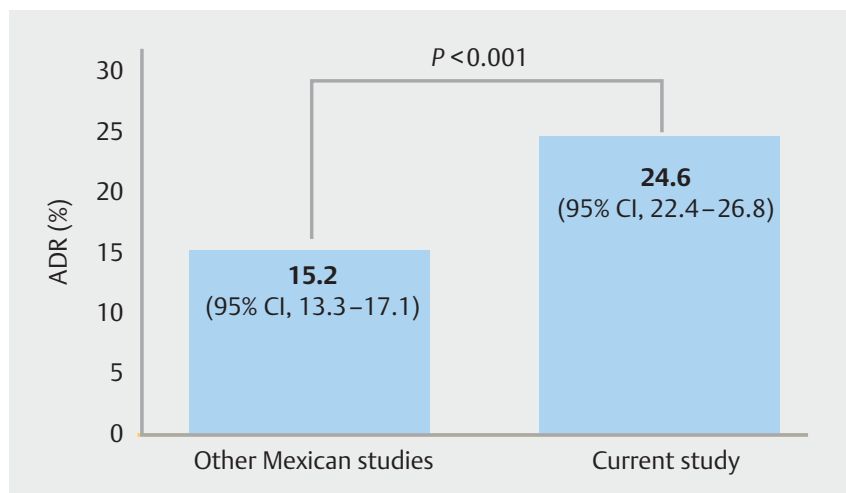

Fig. 1 Adenoma detection rate (ADR). Comparison of previously reported data with results from the present study.

sulted in an increase in the ADR among $39.6 \%$ of endoscopists in a 10-year period [22]. Likewise, the feedback with benchmarking using colonoscopy quality indicators resulted in a sustained annual improvement of $1.5 \%$ in overall ADR in Poland, with $74.5 \%$ of endoscopists improving their ADR [6]. Endocuff- assisted colonoscopy has shown an improvement in ADR in comparison with standard colonoscopy without major adverse events, especially for operators with low to moderate ADRs [23]. We did not include results from colonoscopies using distal attachment devices or other technologies in this study; however, we would like to underline that the results of endocuff-assisted colonoscopies from Mexican studies have shown ADRs as high as $44 \%$ [12].

The mortality-to-incidence ratio (MIR) provides a mean to assess the burden of a disease by presenting mortality after accounting for incidence. The MIR has been found to be an insightful measure of the efficacy of cancer control programs [24]. Mortality and incidence data derived from the GLOBOCAN 2018 showed that the MIR of CRC in Latin American countries is higher in comparison with that of high human development index countries like the United States, Australia, and Western European countries [1]. The MIR of CRC in Mexico, Brazil, Argentina, and Colombia is $0.55,0.55,0.60$, and 0.60 respectively, while in Australia, the United Kingdom, Japan, and the United States is $0.17,0.38,0.41$, and 0.42 respectively [1]. The differences in the MIR of CRC between high and low human development index countries can be explained by the quality of their 


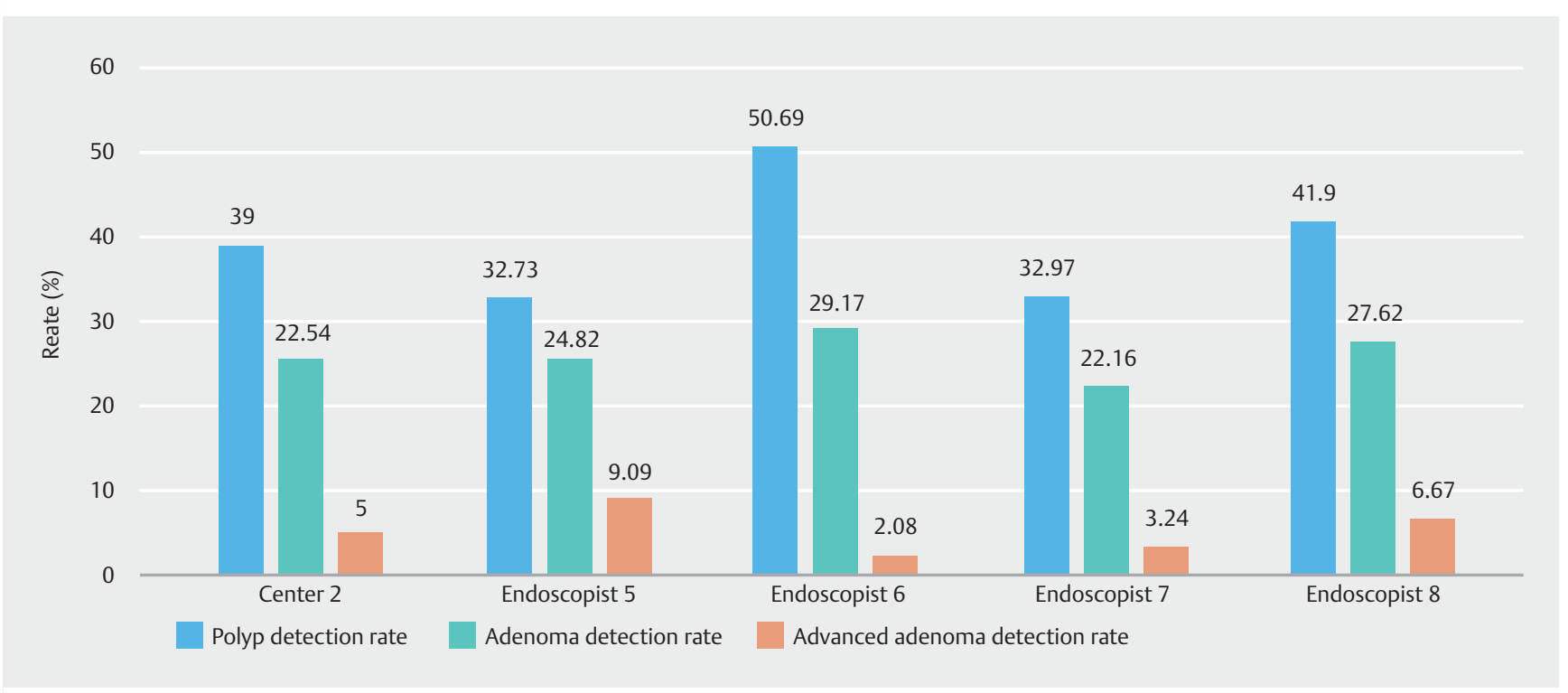

- Fig. 2 PDR, ADR, and AADR from center number 2.

health care systems and screening programs. Developing countries may view a CRC screening program based on colonoscopy as a public health burden [25]. Therefore, before considering a mass screening colonoscopy program, the current quality of colonoscopies performed in Mexico should be first defined and optimized. Mexico does not have a unified national CRC screening program; yet, opportunistic screening colonoscopy is performed by endoscopists in both public and private medical centers.

Detection and prevention of CRC is one of the most important targets in the practice of gastrointestinal endoscopists. Precancerous lesions can be identified by colonoscopy and properly removed, but it is the responsibility of endoscopists to guarantee the quality of all the procedures that she/he performs. To improve quality in colonoscopy, endoscopists must first be aware of quality indicators and be able to compare their performance with that of fellow endoscopists of their country, so they can evaluate and contrast their performance on any improvement intervention [26]. Benchmarking is the process of comparison based on a certain standard to develop better or even optimal practices. The motivation is to provide evidence that the physician's performance is of high quality [27]. Mexican endoscopists who carry out screening colonoscopies are not aware of their results regarding quality indicators, so they are unable to perform benchmarking, but also, they fail to keep a systematic record of their evaluations. This led us to search for a tool to improve our daily practices in colonoscopy procedures. We thus created an application for mobile devices (App) that registers personal and regional quality indicator results for colonoscopy screening, including ADR, PDR, APC, as well as frequency of adequate bowel preparation. The data provided by our App, named ColonApp, will allow Mexican endoscopists to perform benchmarking and improve the quality of its colonoscopy procedures.
The PDR is defined as the number of patients with one or more polyps removed during screening colonoscopy [4]. This performance measure does not require pathology data and may correlate with the ADR; in fact, conversion rates from PDR to ADR have been proposed [28]. The ESGE recommends a minimum PDR of $40 \%$ [29]. The proposed APC minimum detection benchmark is 0.50 for men and 0.20 for women [30,31]. Currently, there is no AADR benchmark recommended in the ASGE or ESGE guidelines [4,5]. The suggested threshold value for AADR is $5 \%$ to $10 \%$; however, there is no proof that these values apply to large-scale screening programs involving centers with lower adenoma detection rates [32]. The APC and the AADR found in our study surpassed the proposed quality benchmarks, but no the PDR.

As strengths of our study, all colonoscopies were performed by certified endoscopists with experience in CRC screening, more than one medical center was included in the investigation, and other quality indicators, such as adequate bowel preparation, were considered. The retrospective nature of the study could be considered an advantage because it reflects real life ADR and is not affected by the performance pressure of endoscopists enrolled in prospective ADR studies. On the other hand, the limitations of the study were mainly the inclusion of diagnosis and screening colonoscopies, and the lack of sufficient data to analyze size of adenomas and other quality indicators, such as withdrawal time. Further studies with a larger sample size and the inclusion of more endoscopy units are needed to better evaluate the quality of screening colonoscopy in Mexico.

\section{Conclusions}

In conclusion, the major finding of our research is that the ADR of the endoscopists working in two tertiary care private hospitals in Mexico City is above that reported in Mexican studies. 
Our results suggest that published data in Mexico is related to poor quality in colonoscopy performance rather than to low adenoma and CRC incidence. The data from this work can generate awareness regarding the great opportunity of improving the quality of colonoscopies afforded to countries with economic developments and health systems similar to Mexico, in the hopes of achieving the expected benefits of colorectal cancer screening.

\section{Competing interests}

The authors declare that they have no conflict of interest.

\section{References}

[1] Bray F, Ferlay J, Soerjomataram I et al. Global cancer statistics 2018: GLOBOCAN estimates of incidence and mortality worldwide for 36 cancers in 185 countries. CA Cancer J Clin 2018; 68: 394-424

[2] Arnold M, Sierra MS, Laversanne M et al. Global patterns and trends in colorectal cancer incidence and mortality. Gut 2017; 66: 683-691

[3] Rex DK, Boland CR, Dominitz JA et al. Colorectal cancer screening: Recommendations for physicians and patients from the U. S. MultiSociety Task Force on Colorectal Cancer. Gastrointest Endosc 2017; 86: $18-33$

[4] Rex DK, Schoenfeld PS, Cohen J et al. Quality indicators for colonoscopy. Gastrointest Endosc 2015; 81: 31-53

[5] Kaminski MF, Thomas-Gibson S, Bugajski M et al. Performance measures for lower gastrointestinal endoscopy: a European Society of Gastrointestinal Endoscopy (ESGE) Quality Improvement Initiative. Endoscopy 2017; 49: 378-397

[6] Kaminski MF, Wieszczy P, Rupinski M et al. Increased rate of adenoma detection associates with reduced risk of colorectal cancer and death. Gastroenterology 2017; 153: 98-105

[7] Corley DA, Jensen CD, Marks AR et al. Adenoma detection rate and risk of colorectal cancer and death. N Engl J Med 2014; 370: 12981306

[8] Bishay K, Causada-Calo N, Scaffidi MA et al. Associations between endoscopist feedback and improvements in colonoscopy quality indicators: a systematic review and meta-analysis. Gastrointest Endosc 2020; 92: 1030-1040

[9] Baker FA, Mari A, Hosadurg D et al. The impact of colonoscopy indication on polyp detection rate. Ann Gastroenterol 2019; 32: 278-282

[10] Penz D, Ferlitsch A, Waldmann E et al. Impact of adenoma detection rate on detection of advanced adenomas and endoscopic adverse events in a study of over 200,000 screening colonoscopies. Gastrointest Endosc 2020; 91: 135-141

[11] Gutiérrez-Serrano R, Vázquez-Mendoza G, García-Jiménez ES et al. Tasa de detección de pólipos en pacientes con síndrome de intestino irritable. Revista Médica MD 2019; 10: 95-99

[12] Andujar-Amor MA C-GM, Manrique MA, Pérez-Corona T et al. Rendimiento diagnóstico del dispositivo Endocuff en la detección de adenomas. Experiencia en el Hospital Juárez de México. Endoscopia 2018; 30: $7-14$

[13] Gonzalez-Fernandez C, Garcia-Rangel D, Aguilar-Olivos NE et al. Higher adenoma detection rate with the endocuff: a randomized trial. Endoscopy 2017; 49: 1061-1068

[14] Peniche-Moguel PA Z-GA, García-Guerrero V, Corral-Medina A et al. Comparación de la prevalencia de adenomas detectados mediante colonoscopio con CAP accesorio (endocuff) versus colonoscopio estándar. Endoscopia 2016; 28: 143-147

[15] Zamora-Morales MZ-GA, García-Guerrero VA, Corral-Medina A et al. Determinación de tasa de adenomas desapercibidos en pacientes con riesgo promedio de cáncer colorrectal con preparación intestinal inadecuada. Endoscopia 2016; 28: 49-54

[16] García-Osogobio ST-ÁF, Méndez N, Uribe-Esquivel M. Results of the first program of colorectal cancer screening in Mexico. Endoscopia 2015; 27: 59-63

[17] de Lascurain-Morhan E. Prevalence of adenomas and carcinomas of the colon. Results of the rectosigmoid exam. Rev Gastroenterol Mex 2001; 66: 131-136

[18] Rex DK, Repici A, Gross SA et al. High-definition colonoscopy versus Endocuff versus EndoRings versus full-spectrum endoscopy for adenoma detection at colonoscopy: a multicenter randomized trial. Gastrointest Endosc 2018; 88: 335-344

[19] Jain M, Vij M, Srinivas M et al. Spectrum of colonic polyps in a South Indian urban cohort. J Dig Endosc 2017; 8: 119-122

[20] Sedlack RE. Training to competency in colonoscopy: assessing and defining competency standards. Gastrointest Endosc 2011; 74: 355366

[21] Pace D, Borgaonkar M, Evans B et al. Annual colonoscopy volume and maintenance of competency for surgeons. Surg Endosc 2017; 31: 2630-2635

[22] Brenner H, Altenhofen L, Kretschmann J et al. Trends in adenoma detection rates during the first 10 years of the German Screening Colonoscopy Program. Gastroenterology 2015; 149: 356-366

[23] Williet N, Tournier Q, Vernet C et al. Effect of endocuff-assisted colonoscopy on adenoma detection rate: meta-analysis of randomized controlled trials. Endoscopy 2018; 50: 846-860

[24] Choi E, Lee S, Nhung BC et al. Cancer mortality-to-incidence ratio as an indicator of cancer management outcomes in Organization for Economic Cooperation and Development countries. Epidemiol Health 2017; 39: e2017006

[25] Delavari A, Bishehsari F, Salimzadeh H et al. Adenoma detection rates in an opportunistic screening colonoscopy program in Iran, a country with rising colorectal cancer incidence. BMC Gastroenterol 2014; 14: 196

[26] Ishibashi F, Fukushima K, Kobayashi K et al. Individual feedback and monitoring of endoscopist performance improves the adenoma detection rate in screening colonoscopy: a prospective case-control study. Surg Endosc 2020: doi:10.1007/s00464-020-07672-8

[27] Leung FW. Benchmarking and quality-screening colonoscopy. J Interv Gastroenterol 2012; 2: 100-102

[28] Francis DL, Rodriguez-Correa DT, Buchner A et al. Application of a conversion factor to estimate the adenoma detection rate from the polyp detection rate. Gastrointest Endosc 2011; 73: 493-497

[29] Rembacken B, Hassan C, Riemann JF et al. Quality in screening colonoscopy: position statement of the European Society of Gastrointestinal Endoscopy (ESGE). Endoscopy 2012; 44: 957-968

[30] Kahi C], Vemulapalli KC, Johnson CS et al. Improving measurement of the adenoma detection rate and adenoma per colonoscopy quality metric: the Indiana University experience. Gastrointest Endosc 2014; 79: $448-454$

[31] Gessl I, Waldmann E, Penz D et al. Evaluation of adenomas per colonoscopy and adenomas per positive participant as new quality parameters in screening colonoscopy. Gastrointest Endosc 2019; 89: 496-502

[32] Coriat R, Lecler A, Lamarque D et al. Quality indicators for colonoscopy procedures: a prospective multicentre method for endoscopy units. PLoS One 20127: e33957 